\title{
THE ANALYSIS OF RISK PROFILE AND FINANCIAL VULNERABILITY OF HOUSEHOLDS IN INDONESIA
}

\author{
Arlyana Abubakar ${ }^{1}$, Rieska Indah Astuti², Rini Oktapiani ${ }^{3}$
}

\begin{abstract}
This paper identifies the vulnerability of household in Indonesia using both Balance Sheet and Financial Margin Approaches with coping strategy analysis in response to financial pressure. The result concluded that the household sector is solvent and sound with high interconnectivity with the non-financial corporation, particularly with banks. The heatmap coping strategies are in the moderate zone. However, it cumulatively tends to change to a high and extreme zone which potentially creates imbalances in the financial system in Indonesia.
\end{abstract}

Keywords: Balance sheet analysis, financial margin, coping strategy JEL Classification: D14, E52, G21

1 Senior economic researcher, Department of Macroprudential Policy, Bank Indonesia; (corresponding author arlyana@bi.go.id).

2 Economic researcher, Department of Macroprudential Policy, Bank Indonesia; rieska_ia@bi.go.id

3 Research Fellow, Department of Macroprudential Policy, Bank Indonesia; rini. oktapiani@gmail.com

Authors would like to thank Alvin Pratama, Taufik Hidayat, and Jazman Ihsanuddin for their contribution to this paper. Views expressed in this paper are solely from authors and do not necessarily represent the views of Bank Indonesia. We also thank reviewers and editor of this journal for their critical evaluation and suggestion on refining this paper. 


\section{INTRODUCTION}

The real sector, including households and corporations, plays a vital role in the economy. The household sector has assets and exposure that are relatively large in the financial industry, indicating that the performance of the household sector can affect the overall financial system. The increased debt or household obligations, amid a sustained slowdown in the economy, prompted the need for monitoring of the household sector to prevent potential imbalances in the financial system from households.

The imbalance risks emanating from the household sector can be transmitted to the financial system through several channels (IMF, 2005). Households are exposed to risk in their capabilities as owners of financial assets in the form of third-party funds, securities, equity assets and insurance, and pension funds. Besides, households are also exposed to risks in their role as fund borrowers from the financial sector, particularly banks. The imbalance occurs when the household cannot pay off the liabilities to the bank, so the bank suffers losses. On the other hand, households experiencing financial difficulties will also reduce spending on consumption, thereby reducing the demand for goods and services that may subsequently have an impact on the economy. As a result, corporations experience a decrease in revenues that could lead to the decline in the ability of corporations in terms of repayment capacity to banks.

The US experience of sub-prime mortgage that led to the global crisis in 2008 showed that credit risks from the household sector could have a significant impact on the economy as a whole. A high interconnection between the household sector and the financial sector could potentially increase systemic risk in the event of a shock in the household sector. Therefore, a broader household risk profile is needed to mitigate the risks stemming from the household's financial imbalance.

Household balances are linked to other sectors balance sheets such as corporations, the public sector and the financial sector from both assets, and liabilities. Household exposure to all sectors of the economy can be analyzed using the Balance Sheet Approach (BSA) method as the IMF has done it. BSA is used for surveillance of financial system stability by analyzing position data, both assets and liabilities of each sector to measure risk in a country's economy (Haim \& Levy (2007) and Allen et al. (2002)).

In 2014, Bank Indonesia in collaboration with other related institutions began to prepare National and Regional balance sheets starting with the preparation of Financial Account (FA). Through the use of National Balance Sheet (NBS) data, the economy can be viewed as an integrated system of sectoral balance sheets, comprising government sectors, central banks, households, banks, corporations, non-banking financial institutions, and external areas. The availability of integrated NBS data can illustrate inter-sectoral linkages and economic conditions so that it can be used to further analyze the inter-sector financial risks, financial imbalances between institutions, domestic, and overseas. It is expected to obtain information related to household sector risk profile as well as linkages between the household sector and other economic sectors through a more in-depth analysis of NBS data. Also, the study features a vulnerability assessment of households primarily derived from credit risk using the financial margin indicator. Using the Bank Indonesia Household Survey (SNRT BI) data in 2015, the financial margin values 
for each sample in the survey can be used to indicate whether the household is experiencing distress on its financial condition or not.

This paper aims to identify the characteristics and risk profile of the household sector in Indonesia. Also, it develops an indicator of household financial imbalance through the Balance Sheet Approach (BSA) and Financial Margin Approach (FMA). The present paper further maps household heatmap coping strategies in facing of financial pressures, referring to the calculation of the balance indicator.

This paper has several limitations, namely the limited data on individual households. Second, financial margin analysis is limited to a regional coverage (12 provinces) and the number of samples used in the 2015 SNRT so as not to be aggregated nationally. Besides, the analysis did not involve inferential modeling and testing.

The next section of this paper reviews the theories and literature that are strictly related to this topic. The third section describes the research methodology, while Section 4 presents the results of calculating and mapping the level of household equilibrium in Indonesia. The fifth section presents the conclusions and closes this paper.

\section{THEORY}

\subsection{Financial Margin}

Financial margin is a liquid asset held by households after deducting the cost of debt including the cost of interest and principal debt as well as total household expenditures. This indicator represents household resilience to changes in macroeconomic conditions such as an increase in interest rates or a decrease in income. Furthermore, the financial margin may also provide information about the risk of a household's default on loans from financial institutions such as large banks that can affect the stability of the financial system (Vatne, 2007).

Households with negative financial margins can be considered as vulnerable households. The share of vulnerable households can be a crucial indicator in monitoring household resilience to various shocks such as employment shock as well as changes in interest rates, asset prices, exchange rates, and repayment vehicle yields (Albacete and Fessler, 2010).

To analyze the vulnerability of households, the financial margin can also be used as a financial distress indicator where households are assumed to be distressed when they have negative financial margins. The financial margin represents the difference between household income after tax and main expenditure including food, energy, transportation, health and rental, and debt repayment expenses (Hlavac, Jakubik, \& Galuscak, 2014).

Pratama \& Hidayat (2015) explains that financial margin can be used as a proximate measure of household credit risk that can describe the ability of households to pay both short-term and long-term debts. Households with negative financial margins are considered to be households that are in financial trouble and are characterized by the inability to meet basic needs and repay the debt so that households tend to have high default potentiality of repayment.

The vulnerability analysis of households in Norway using the financial margin indicator conducted by Vatne (2007) through the Income and Property Statistics 
for Household 1987-2003 data, showed that 13\% of households in Norway are vulnerable households or have financial value with negative margin in 2003, where the ownership of the household debt reached $17 \%$ of total household debt.

By income group, as many as $20 \%$ of the highest income households own $1 / 3$ of the total household debt, where the debt held by vulnerable households is relatively small (7\%). In the lowest income households group, more than $50 \%$ of the debt is owned by vulnerable households. Groups of households with productiveaged household heads (24-35 years) have almost 30\% of total household debt where $40 \%$ of the debt is owned by vulnerable households.

Using OENB's Household Survey on Housing Wealth 2008 (HSHW, 2008) and financial margin calculation method, Albacete \& Fessler (2010) found that the share of vulnerable households in Austria ranged from $9.2 \%$ to $15.6 \%$. By income group, the highest income households have a relatively small percentage of susceptible households that varies around 1\%. While the lowest income households have a share of households that reached $56.7 \%$ to $70.5 \%$. In general, vulnerable households in Austria tend to have low incomes, massive debts, and are headed by women.

Bilston, Johnson, \& Read (2015) conducted a household vulnerability analysis using a financial margin approach using the Households, Income, Labor Dynamics in Australia (HILDA) survey data. The results explained that the share of vulnerable households in Australia reached $12 \%$ in $2002,10 \%$ in 2006, and $8 \%$ in 2010. Based on demographic characteristics, vulnerable households are those contracting household with relatively low income.

Another study, conducted by Johansson \& Persson (2006) in Swedish households using HEK Survey data, found that the share of vulnerable households in Sweden accounted for $6.3 \%$ of all households with debts in which the household holds $5,6 \%$ of the total household debt in Sweden.

In the Indonesian case, Effendi (2015) used a financial margin approach to analyze the vulnerability of Indonesian households by utilizing the 2012 National Socio-Economic Survey (SUSENAS) data and found that the average share of vulnerable households in Indonesia is $5.39 \%$. Based on income deciles, the most significant share of vulnerable households is found in decile-1 (lowest income class), reaching $41 \%$. Meanwhile, the percentage of vulnerable households in decile-10 (highest income class) was recorded relatively small, i.e., less than $1 \%$. The share of households based on income deciles tends to decrease as income increases.

Pratama \& Hidayat (2007) also analyzed household vulnerability through financial margin indicator by using the 2007 Indonesian Family Life Survey (IFLS) data. In this research, there are two approaches, direct and indirect. In the immediate approach, the value of financial margin is calculated based on the difference between per capita expenditure which is the proxy of income and spending with a monthly payment. Meanwhile, the value of financial margin in the indirect approach is obtained from the difference between household expenditure which is the proxy of income with predicted essential consumption and monthly payment.

The result of the analysis, using the direct approach, showed that in total there are $16 \%$ of Indonesian households that are vulnerable to default with debt 
ownership of $48 \%$. Of the total households with debt to banks, $26 \%$ were vulnerable households with ownership of debt that reaches $52 \%$.

The analysis, generated by the indirect approach, tends to be overestimated due to the double counting of the reduction in household expenditure as a proxy of income with basic consumption accounted for by the value of household expenditure. In total, the share of vulnerable households reached $49 \%$ with debt ownership of $45 \%$. This result is not much different for households who have debt only to banks where as many as $49 \%$ of these households are vulnerable to default and have a debt of $46 \%$.

By demographic characteristics, the results of the direct approach indicated that households with fragile share and high debt holdings are male-headed households at productive age with homes. While in the indirect method, household groups that have a share of vulnerable households with high debt holdings are households with houses as debt guarantees.

\subsection{Household Coping Mechanism}

There are three choices of coping strategies that can be done by the household which includes risk prevention, risk mitigation, and risk coping strategies (Tesliuc dan Vakis, 2004). A risk prevention strategy is a strategy used before a risky event occurs and is carried out with the purpose of reducing the likelihood occurrence of the event that can affect the welfare of the household. Unlike the risk prevention strategy, risk mitigation strategies are carried out by households to reduce the impact of an event that has been predicted to occur. Meanwhile, risk coping strategies are a household strategy when risky events have occurred. The general form of the strategy may be the withdrawal of savings, borrowing money, relying on assistance from private or government agencies, and so on.

These risk management strategies can be informally carried out between households (informal, based arrangements), market-based arrangements that are risk handling with the help of financial institutions, and public arrangements that are handling household risks with the assistance of the government.

Of the three risk management strategies mentioned above, the risk coping strategy is the most important strategy for households because it can measure the magnitude of household resilience to certain events that can cause household financial imbalance that if not handled properly can have an impact on the occurrence of financial pressure (distress) (Lusardi et al. (2009) and WHO (1998)).

Furthermore, Snel \& Staring (2001) and Bhrami \& Poumphone (2002) revealed that in general, coping strategies are carried out primarily when households are experiencing economic difficulties which may include strategies to find solutions to problems, strategies for dealing with stress and strategy to develop defense mechanisms. The form of coping strategies undertaken by households tends to vary, among others, can be either limitation of the expenditure or getting the additional income just to meet the basic needs and keep the level of welfare of life (not reduce).

Also, PEP-CBMS Network Coordinating Team (2011) explained that household risk coping strategies are conducted with the aim of minimizing the impact of pressure on the level of well-being. In general, these strategies are complicated 
in that they depend on exogenous and endogenous factors such as household characteristics, experience, local economics, infrastructure, and networks.

Based on the classification of the generated effects (severity), risk coping strategies can be divided into three as follows.

1. Non-Erosive Coping includes borrowing strategies; reducing food consumption; substituting food for cheaper; reducing unnecessary spending; and selling nonproductive assets.

2. Erosive Coping includes a high-interest borrowing strategy; sell productive assets such as land, animals, farmland, other productive equipment; borrowing wages for the next period payment; and employing minors.

3. Failed Coping is a situation where households have a high dependence on others to meet their needs, migrate, steal, beg, and so forth.

The World Bank (2011) explained that there are shocks from the labor market such as termination of employment, credit markets such as rising lending rates, product markets such as rising food prices and reducing government subsidies to society (in general) will be responded by the public through the increasing of revenues either via withdrawal of savings or doing additional work, and so on. Another response that can also be done by households regarding expenditure is to reduce spending including expenditures on valuables, food, education, health, insurance, and so forth.

The failure of the household to respond to the shock will affect the decline in the level of household welfare represented by the decrease in financial assets in the form of saving, decreasing non-financial assets, decreasing the accumulation of human capital such as employing children under the age of work, and so forth. More explicitly, the interaction between household shock sources and household responses and their impact on household welfare can be seen in the following diagram. 


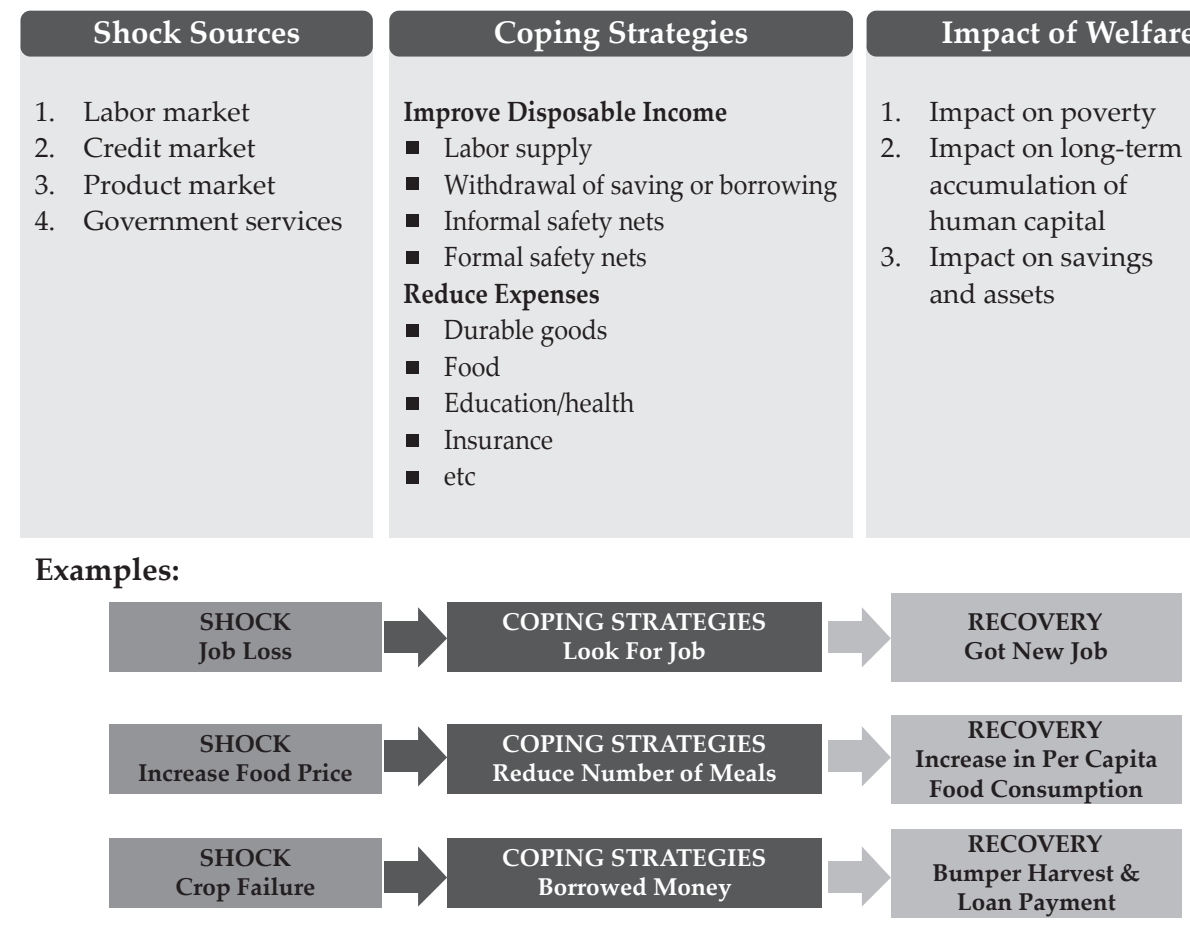

Source: World Bank (2011) in the PEP-CBMS Network Coordinating Team (2011)

Chart 1. Interactions between Shock Sources and Coping Strategies as well Impacts on Household Welfare

In more depth, coping strategies taken by households in response to particular pressures or events can also determine the degree of vulnerability they encounter. The Food Security \& Early Warning Vulnerability assessment manual (USAID, 1999) describes that coping strategies undertaken by households can fall mainly into two categories: adaptation and divestment strategies for divestment of both liquid assets and productive assets. Both strategies can reflect the extent of the vulnerability faced by households. The level of vulnerability of households is divided into three, namely moderate, high, and extreme vulnerability level.

Households which have coping adaptation strategies in response to an event occurring, generally have relatively moderate vulnerability levels. Meanwhile, households that choose to divest on liquid assets tend to have high levels of vulnerability or even extreme especially for households who divest on productive assets.

The link between coping strategies and household vulnerability levels can be seen more comprehensively on heatmap coping strategies adapted from the Food Security \& Early Warning Vulnerability USAID (1999) assessment manual and has been used internationally to identify household vulnerability levels by looking at what strategies are used in facing of financial pressures. 


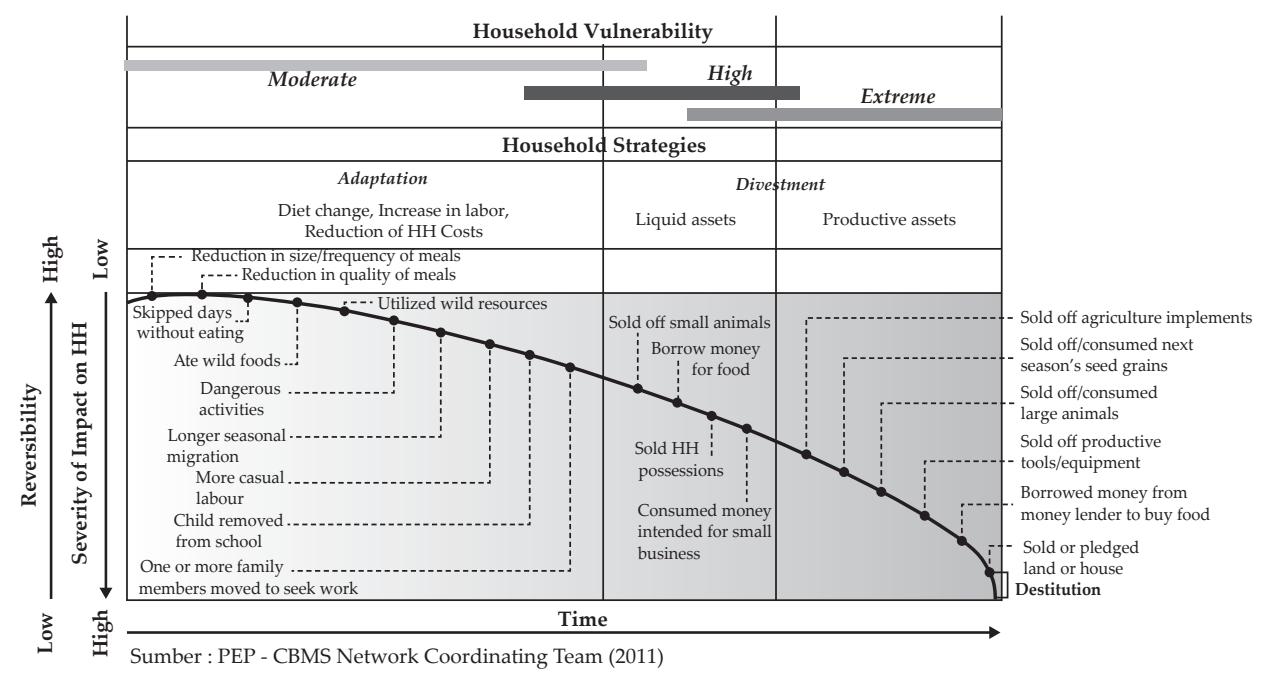

Chart 2. Heatmap Coping Strategies

\section{METHODOLOGY}

\subsection{Model Framework}

The framework in this research uses two approaches, namely macro (aggregate) using Balance Sheet Approach method and micro by using Financial Margin Approach. The macro analysis using BSA provides information on the household sector risk profile obtained either through individual sector risk analysis of the sector or an interconnectedness risk analysis of households with other institutional sectors. Individual household risk analysis is obtained through a balance sheet risk indicator, while the risk analysis of household linkages with other sectors is obtained through BSA matrix.

The FMA is done by using two approaches, namely income approach and expenditure approach. Both methods result in the share and demographic characteristics of households that have negative financial margins and further defined as vulnerable households. The results of such analysis can be input in decision making primarily for the provision of household credit by financial institutions.

In addition to both methods, the household vulnerability can also be assessed based on coping strategies taken in facing financial pressures. Information related to household coping strategies was obtained through survey results based on three primary answers selected by respondents in facing financial difficulties. The behavior of household coping strategies can lead to vulnerability as actions taken can directly impact the financial sector, such as withdrawing deposits in banks and so on, to affect the overall balance of the financial system. Also, information on household demographic characteristics obtained through FMA can also be an input in coping strategies given that the strategies adopted by vulnerable households potentially lead to higher vulnerability. 




Chart 3. Domestic Vulnerability Framework Analysis

\section{Balance Sheet Approach (BSA)}

Analysis of household vulnerability in aggregate includes analysis of individual household risk profile of sectors as well as risk analysis of household linkages with other institutional sectors such as corporations, banks, and IKNB. An approach that can be used to analyze the vulnerability of households is BSA.

BSA is an approach that uses sectoral balance sheet data to analyze the interconnection between economic sectors and analyze the position of assets and liabilities of a sector and its changes caused by shocks in certain sectors and affect other sectors through the balance sheet channel (IMF, 2015).

The sectoral balance sheet data used in this study is national and regional data of FABS Bank Indonesia in 2015. The data is then used in calculating the balance sheet risk indicator to identify household risk profile. Risk indicators, used concerning data availability, are liquidity risk indicators such as the ratio of saving to expenditure and solvency risk such as the ratio of liabilities to assets and liabilities to GDP.

Also, interconnection analysis between the household sector and other sectors uses the whom-to-whom matrix or BSA matrix in the FABS data. The type of BSA matrix used is the BSA matrix for the net financial position indicator that can describe the household's financial position towards other sectors and is an indicator of the vulnerability of the economic sector. In general, the value of the net financial position is derived from the difference in total financial assets subtracted the total liabilities. The negative value of the net financial position implies that the sector is facing financial problems where the total financial assets are insufficient to meet all of the obligations (IMF, 2015). 


\section{Financial Margin Approach (FMA)}

The identification of household vulnerability is also individually done to complement the results of the aggregate analysis individually using FMA. FMA is an approach used to calculate household margins derived from residual income after deducting expenditure, both basic expenditures, and expenditures to pay principal installments of debt and interest defined as financial margin (Bilston, Johnson, \& Read, 2015).

Financial margins measure the ability of households to cover debts, both shortterm and long-term. Households with negative financial margins are defined as vulnerable households. Such vulnerability, if not addressed properly, may result in difficulties in meeting basic needs and repay debt, increasing the possibility of default to the counterparty (Pratama \& Hidayat, 2015).

This study focuses on households that have the debt to banks and have negative financial margin value. Such households may generate financial imbalances through exposure to other sectors, particularly banks.

The data used to calculate the financial margin of each household is the data of SNRT 2015. The value of financial margin is obtained through two approaches, namely income approach and expenditure approach. In the income approach, the financial margin value of households is obtained from the difference between income with expenditure for basic consumption and debt repayments. This approach is adapted from the Albacete \& Fessler (2010) study utilizing OeNB's Household Survey on Housing Wealth 2008 (HSHW, 2008) data to analyze the vulnerability of households in Austria. Mathematically, the calculation of financial margin value by using income approach is as follows.

$$
F M_{i}=Y_{i}-B C_{i}-D S_{i}
$$

Where $Y_{i}$ is the income of the household, $B C_{i}$ represents the basic consumption of the household, and $D S_{i}$ is the installment of household debt.

The household income in the 2015 SNRT is the total income of all ART within one year. The basic consumption component ${ }^{4}$ is referring to the type of necessary expenditure used by BPS to calculate the poverty line, which includes food consumption, housing and household facilities, clothing and fashion, and the consumption of various goods and services. Meanwhile, the value of installments of household debt includes short-term and long-term debt repayments.

A second approach is an expenditure approach which is an expenditure approach where income data is proxied through household consumption (total consumption) which is done to minimize error-term (error) that occurs due to the use of revenue data from survey results that tend to be biased. Mathematically, the value of financial margin is calculated by the following formula.

$$
F M_{i}=C_{i}-D S_{i}
$$

4 Information can be obtained at http://bps.go.id/Subjek/view/ id/23\#subjekViewTab1 I accordion-daftar-subjek1. 
where $C_{i}$ is the total consumption of a household and $\mathrm{DS}_{\mathrm{i}}$ shows the installment of household debt.

The total household consumption is calculated from all of the consumption items contained in SNRT 2015 data such as food consumption; housing and household facilities; clothing and fashion; various goods and services; recreation, taxes, levies, donations, insurance and zakat; party and ceremonial/feast purposes; transportation, service vehicles and fuel; and other consumption. The Basic Consumption variable $(\mathrm{BC})$ is not included in the calculation to avoid double counting because it is included in the total consumption.

\subsection{Data}

Data used in this study include the 2015 National and Regional Financial Accounts \& Balance Sheets (FABS) data used to analyze the aggregate household vulnerability and the 2015 Household Survey (SNRT) data used to identify the vulnerability of individual households.

\section{National and Regional FABS Data (2015)}

The FABS data is part of the Integrated Economic Account, which covers the framework of sectoral accounts developed through cooperation between Bank Indonesia (BI) and the Central Bureau of Statistics (BPS), in meeting the needs of integrated data and can describe the condition of the economy and financial system and the risk in an economic sector which may affect the overall financial system. The data requirement is in line with one of the data Gaps Initiatives \# 15 of G-20 countries that were initiated by International Monetary Fund (IMF) and Financial Stability Board (FSB) in 2009.

BI and BPS multi yearly have implemented the effort to fulfill the recommendation since 2012. As part of the effort, BI has performed the preparation of FABS data as part of the sectoral account framework for each institutional sector, both nationally and regionally since the beginning of 2014 under the Strategic Program \# 4 Architecture of Strategic Functionality of Bank Indonesia (AFSBI) Preparation of National and Regional Balance Sheet.

FABS data is useful for analyzing inter-sectoral linkages, financial imbalances in individual sectors and analyzing the contagion effect of shock in a sector against other sectors that may cause systemic risks and potentially trigger a crisis. Regionally, FABS data is also useful for determining regional financial systems comprehensively and identifying regional financial imbalances.

In more detail, FABS data includes Financial Account (FA) and Balance Sheet (BS) data. FA data is the data of inter-sector asset and financial liabilities transactions, which shows the financial flows between institutional sectors both national and regional (certain regions). Meanwhile, the BS data is the position data of assets and liabilities owned by the institutional sectornationally or regionally (in a particular region) as well as in certain period. The BS data consists of the initial position balance sheet and the end position balance sheet. 
FABS data are classified based on the classification of the institutional sector as well as financial instruments regarding assets and liabilities. The classification of the institutional sector used in the national FABS is as follows.

Table 1.

Classification of Institutional Sectors at National FABS

\begin{tabular}{lll}
\hline \multicolumn{1}{c}{ Institutional Sector } & \multicolumn{1}{c}{ Institutional coverage } \\
\hline 1. Non-Financial Corporation (NFC) & Public and Private Non-Financial Companies \\
2. Central Bank (CB) & Bank Indonesia \\
3. Deposit-taking other than the central bank & $-\quad$ Conventional commercial bank \\
(ODC) & - Islamic commercial bank \\
& - Conventional BPR \\
& - Islamic BPR \\
4. Other Financial Corporation (OFC) & - Pension Funds \\
& - Insurance \\
& - Finance Companies (Finance Companies, \\
& & Pawnshops, Cooperatives, Savings and Loans, \\
& & and Indonesia Exim Bank) \\
& & Financial Auxiliary (OJK, Forex Traders, KSEI, \\
5. Central Government (CG) & Central Government and excluding Social Security \\
6. Local Government (LG) & Local Government (Provincial, District, and City \\
7. Household (HH) & Government) \\
8. Rest of the World (ROW) & Household and Non-Profit Institution Serving \\
\hline
\end{tabular}

Source: Bank Indonesia (2015)

The classification of the institutional sector used in the regional FABS is based on a center of predominant economic interest in which a sector is considered as a part of a regional institutional sector when it has a large regional economic interest center. The classification of the institutional sector in the regional FABS is as follows. 
Table 2.

Classification of Institutional Sectors at (FABS) Regional level

\begin{tabular}{lll}
\hline \multicolumn{1}{c}{ Institutional Sector } & \multicolumn{1}{c}{ Institutional Coverage } \\
\hline 1. Non-Financial Corporation (NFC) & Public and Private Non-Financial Companies \\
2. Deposit-taking other than the central & - & Conventional Commercial Bank \\
bank (ODC) & - & Islamic Commercial Bank \\
& & Conventional BPR \\
& & Islamic BPR \\
3. Other Financial Corporation (OFC) & - & Pension Funds \\
& & Insurance \\
& & Finance Companies (Finance companies, pawnshops, \\
4. Local Government (LG) & cooperatives, savings, and loans) \\
& Local Government (Provincial, District, and City \\
5. Household (HH) & Government) \\
6. Rest of Indonesia (ROI) & Household and Non-Profit Institution Serving Household \\
& Other sectors outside the region but still in the region of \\
7. Rest of the World (ROW) & Indonesia (Rest of NFC, Central Bank, Central Government, \\
& dan Rest of Others) \\
\hline
\end{tabular}

Source: Bank Indonesia (2015)

From the instrumental aspect, the classifications of financial instruments used in FABS data are Monetary gold and SDRs; Debt securities; Equity and investment fund share/units; Financial derivatives and employee stock options; Currency and deposits; Loans; Insurance, pension and standardized guarantee schemes; and Other accounts receivable/payable.

\section{SNRT Data (2015)}

Microdata, used in this research, is the 2015 SNRT data which is a routine survey result yearly conducted by Bank Indonesia. SNRT began in 2006 and was reimplemented in 2015 with different sample frameworks and aims to examine the structure of households' balance sheets in Indonesia, especially households that are expected to have access and influence to the banking system, establishing essential useful data for designing surveillance systems and a nationally representative balance sheet. Information on household balance in the 2015 SNRT data was obtained through three questionnaires, namely Household Questionnaire (KRT), Household Expenditure Questionnaire (KPRT), and Independent Individual Questionnaire (KIB).

The SNRT (2015) is implemented simultaneously in 12 provinces representing $71 \%$ of Indonesia's population based on the National Socio-Economic Survey (SUSENAS) in the first quarter of 2013. These provinces include North Sumatra, West Sumatera, South Sumatera, DKI Jakarta, West Java, Central Java, East Java, Bali, South Kalimantan, East Kalimantan, North Sulawesi, and South Sulawesi.

The number of households being sampled by the 2015 SNRT in the 12 provinces is 2,170 households. The sample is determined by taking into account 
the percentage of the population working in each province as well as the average number of household members (ART) in each household.

Furthermore, the household balance sheet data in the SNRT (2015) can also be used for several analyzes such as macro analysis or analysis of household income nationally or provincially, microanalysis or analysis of household assets and household access to banking, household debt analysis or behavioral analysis of household debt, as well as analysis of household conditions, and resistance to crises.

\section{RESULTS AND ANALYSIS}

\subsection{Stylized Fact}

In 2015, households were the most significant contributor to the national assets, accounting for $33 \%$ of the total national economic assets, most of which are financial assets. The placement of household financial assets is still dominated by equity fund disbursement mainly to non-financial corporations accounting for $47 \%$ of financial assets followed by third-party funds channeling to banks (42\%).

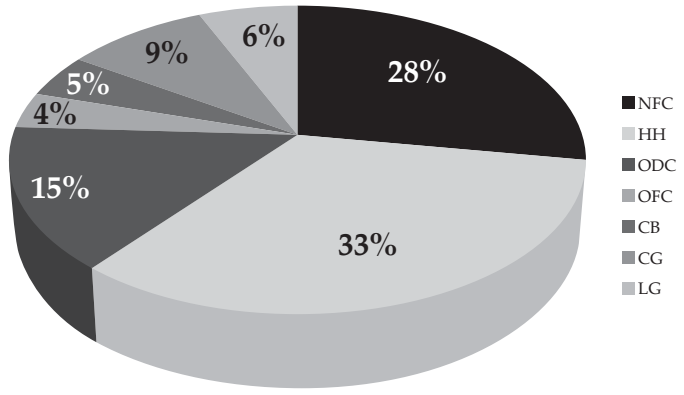

Description:

NFC : Non-financial corporation

$\mathrm{HH}$ : Households

ODC : Banking

OFC : Non-Bank Financial Institutions

CB : Central Bank

CG : Central Government

LG : Regional Government

Graph 1. Composition of National Assets Per Economic Sector

The Composition of Household Assets

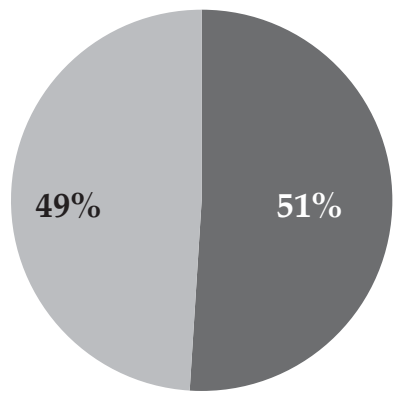

The Composition of Household Financial Assets

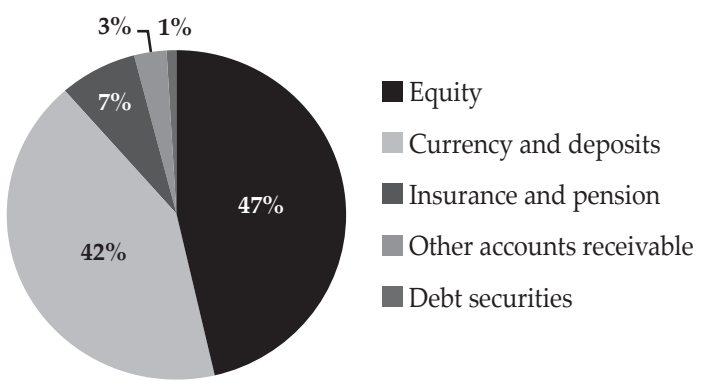

non-Financial Asset $\quad$ Financial Asset

Graph 2. Composition of Household Assets 
Regarding financing, the majority of household debt sources came from banks reaching $83 \%$ followed by IKNB (12\%) and non-financial sector (5\%). Household debt instruments are dominated by loans (97\%) mostly from banking. The share of individual loans to total bank loans was $44 \%$ in 2015 , mostly used for the fulfillment of consumption (61\%).

Sources of Household Financing

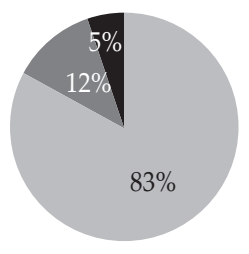

Bank

IKNB
Non-Financial

Graph 3. Financing Sources, Financing Instruments, and Household Based Credit Usage

Loans

Other accounts payable
Household Credit by Usage Instrument

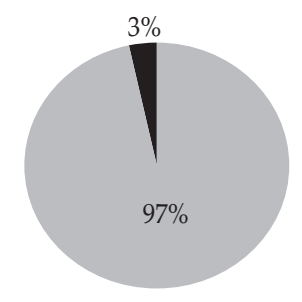

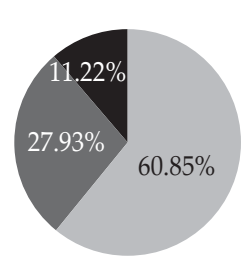

Consumption

Capital Asset

Investment

Spatially, the province with the largest share of household financial assets to GRDP is DKI Jakarta with $132.26 \%$, whereas the majority of the assets are channeled to non-financial corporations in equity (51\%), implying the importance of the role of the household sector to the economy in the Province of DKI Jakarta through financing to corporations that can be used for business expansion.

The composition of household financial assets in DKI Jakarta is much higher than the obligation, indicating that Jakarta household sector has the potential to become a source of financing for the regional economic activity of DKI Jakarta.

Table 3.

Financial Assets and Domestic Liabilities by Province (\% to GRDP)

\begin{tabular}{|c|c|c|c|c|c|c|c|c|}
\hline \multirow[b]{2}{*}{ Balance Sheet } & \multicolumn{8}{|c|}{ Province } \\
\hline & DKI Jkt & $\begin{array}{l}\text { West } \\
\text { Java }\end{array}$ & $\begin{array}{l}\text { East } \\
\text { Java }\end{array}$ & $\begin{array}{c}\text { East } \\
\text { Kalimantan }\end{array}$ & $\begin{array}{c}\text { North } \\
\text { Sulawesi }\end{array}$ & $\begin{array}{c}\text { North } \\
\text { Sumatera }\end{array}$ & $\begin{array}{c}\text { West } \\
\text { Sumatera }\end{array}$ & $\begin{array}{c}\text { South } \\
\text { Sumatera }\end{array}$ \\
\hline Financial Asset & $132.26 \%$ & $39.01 \%$ & $38.95 \%$ & $30.19 \%$ & $38.52 \%$ & $28.60 \%$ & $24.34 \%$ & $35.07 \%$ \\
\hline Liabilities & $16.87 \%$ & $14.28 \%$ & $11.73 \%$ & $6.75 \%$ & $26.01 \%$ & $14.78 \%$ & $14.78 \%$ & $14.45 \%$ \\
\hline
\end{tabular}

Source: RFABS (2015)

* Some provinces can not be shown because the data are not complete 


\subsection{Vulnerability Analysis Using the Balance Sheet Approach (BSA)}

The analysis of household vulnerability, using balance sheet risk indicator, indicated that generally, the liquidity and solvency risk indicator is relatively stable, although it has experienced pressure as a result of the continuing economic slowdown in 2015. From the solvency side, Liabilities to Asset and Liabilities to GDP of households are under $21 \%$ with a downward trend. The decline in Liabilities to Asset indicator value in 2015 was triggered by the growth of financial assets reaching $20 \%$ (yoy) which is much higher compared to the growth of liabilities of $6 \%$ (yoy). The slowing growth in household liabilities also led to a decline in the value of the Liabilities to GDP indicators from the previous period, indicating that the household sector in Indonesia is quite solvent, especially in covering short-term and long-term debt in 2015.

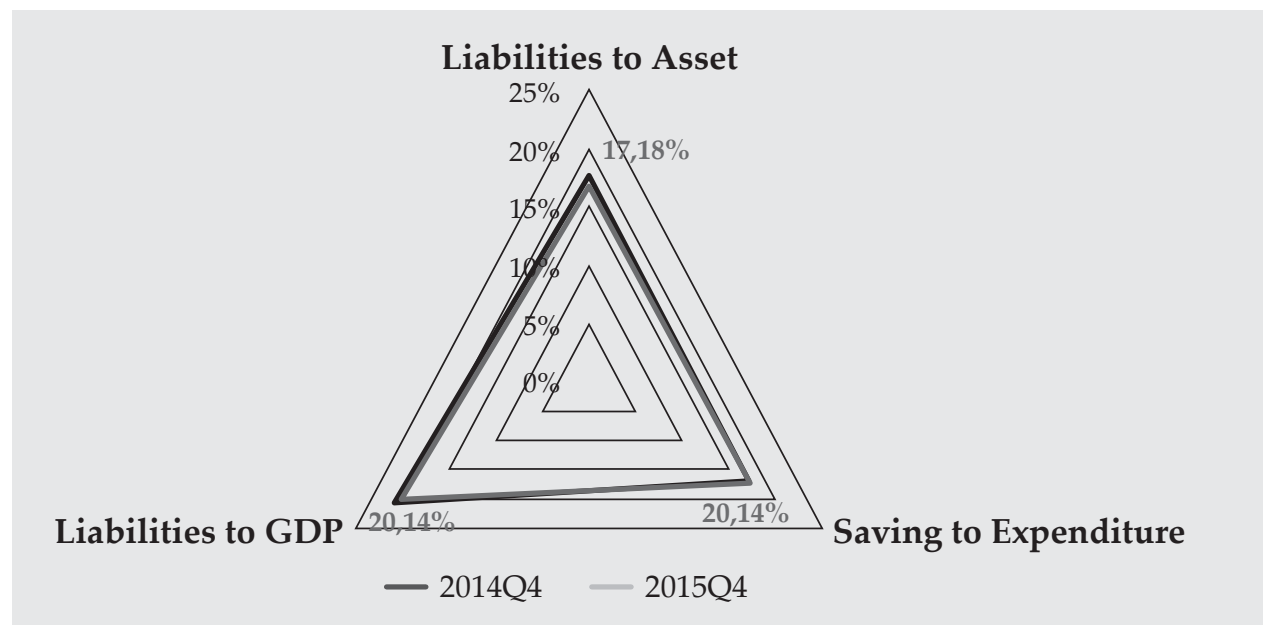

Source: NFABS 2015, processed data

Graph 4. Balance Sheet Risk Indicator

Cumulatively, the liquidity risk indicator proxied by the saving ratio showed an increasing trend compared to the previous period as a result of the increased growth of household savings to banks. The increase in household liquidity implies that households have sufficient liquid assets to meet basic needs and repay shortterm debt.

Based on the BSA matrix of net financial position indicators, the household sector was the sector with the most significant financial surplus in 2015, which is represented by the total net financial position value representing $39.68 \%$ of the GDP. The value of the net financial position of households, among others, comes from the ownership of financial assets that reached $32 \%$ of the national financial assets, implying the importance of the role of the household sector in the economy as one of the largest sources of domestic financing. The distribution of household financial asset (majority) goes to the non-financial corporate sector with the net financial position value of households to the corporation that reached $28.95 \%$ of GDP. 
Table 4.

BSA Net Financial Position Matrix in the Q4 of 2015

\begin{tabular}{|c|c|c|c|c|c|c|c|c|c|}
\hline \multirow{12}{*}{ 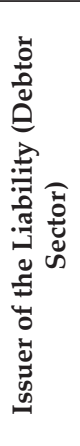 } & \multicolumn{9}{|c|}{ Holder of Liability (Creditor Sector) } \\
\hline & & NFC & HH & ODC & OFC & CB & CG & LG & ROW \\
\hline & \multicolumn{9}{|c|}{ (In percent of GDP) } \\
\hline & \multirow{2}{*}{$\begin{array}{l}\text { TOTAL } \\
\text { NFC }\end{array}$} & $-70.34 \%$ & $39.68 \%$ & $0.98 \%$ & $0.81 \%$ & $1.10 \%$ & $-14.26 \%$ & $2.31 \%$ & $39.72 \%$ \\
\hline & & & $28.95 \%$ & $6.19 \%$ & $1.67 \%$ & $-1.76 \%$ & $5.80 \%$ & $0.9 \%$ & $28.60 \%$ \\
\hline & HH & $-28.95 \%$ & & $-6.44 \%$ & $-1.90 \%$ & $-2.08 \%$ & $-0.42 \%$ & $0.11 \%$ & $0.00 \%$ \\
\hline & ODC & $-6.19 \%$ & $6.44 \%$ & & $1.14 \%$ & $-7.61 \%$ & $-1.42 \%$ & $1.56 \%$ & $5.10 \%$ \\
\hline & OFC & $-1.67 \%$ & $1.90 \%$ & $-1.14 \%$ & & $-0.13 \%$ & $-2.04 \%$ & $0.00 \%$ & $2.27 \%$ \\
\hline & СВ & $1.76 \%$ & $2.08 \%$ & $7.61 \%$ & $0.13 \%$ & & $-0.15 \%$ & $0.03 \%$ & $-12.57 \%$ \\
\hline & CG & $-5.80 \%$ & $0.42 \%$ & $1.42 \%$ & $2.04 \%$ & $0.15 \%$ & & $-0.27 \%$ & $16.32 \%$ \\
\hline & LG & $-0.88 \%$ & $-0.11 \%$ & $-1.56 \%$ & $0.00 \%$ & $-0.03 \%$ & $0.27 \%$ & & $0.00 \%$ \\
\hline & ROW & $-28.60 \%$ & $0.00 \%$ & $-5.10 \%$ & $-2.27 \%$ & $12.57 \%$ & $-16.32 \%$ & $0.00 \%$ & \\
\hline
\end{tabular}

Source : NFABS 2015, data diolah

Equity instruments dominate household financing of the non-financial corporate sector ${ }^{5}$ of which $98 \%$ of household financial assets in the form of capital (46.41\% of total financial assets) are disbursed to non-financial corporations. The amount of household financing of the non-financial corporation's sector showed the high interconnection between the two sectors.

This causes the household sector to tend to be exposed to capital loss risk or liquidity risk when the corporation is under financial pressure or even default. The risk of capital loss occurs when a household sells an equity asset in the form of a corporation stock at a price lower than the purchase price. Liquidity risk occurs when the equity asset is difficult to liquidate, mainly due to adverse market sentiment over the company's long-term financial condition.

Also, BSA net financial position matrix also showed a high interconnection between household sector and banking. The value of household financial assets in the form of deposits (currency \& deposit) of $42.15 \%$ is dominated by the distribution of deposits to the banking sector that reached $92 \%$. Thus, the banking sector tends to be exposed to the risk of withdrawal of funds that can be done by households especially when experiencing a financial deficit to meet liquidity needs.

More comprehensively, the financial interconnection between the household sector and the banking sector, the household sector with non-financial corporations and other sectors can be seen in the graph below.

5 Includes ownership of corporate equity by another corporation, assuming ultimate shareholder is an individual or a household 


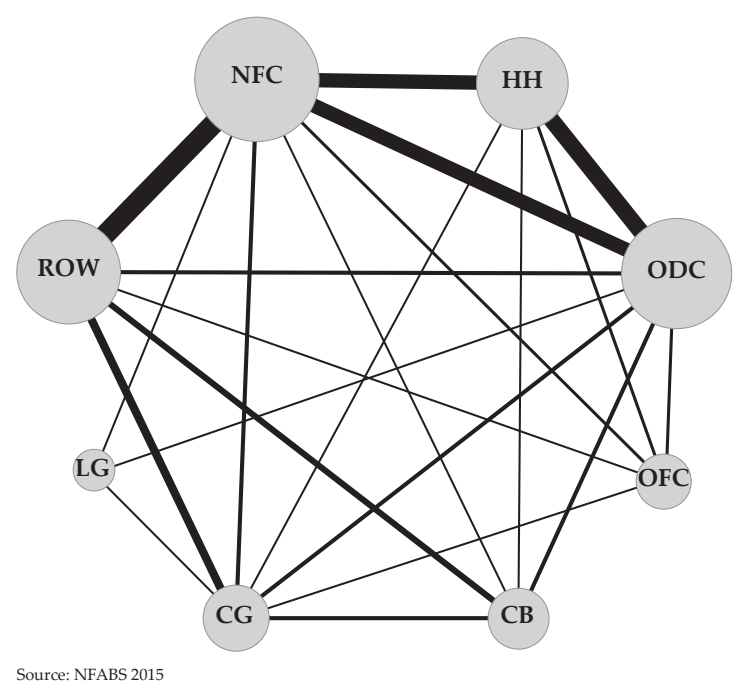

Graph 5. Network Gross Exposure ${ }^{6}$ on the Q4 of 2015

Meanwhile, the spatial analysis of household financial assets by instruments showed that in general households in some provinces in Indonesia (in the majority) still disburse financial assets in the form of deposits in banks. Also, household contributions in some provinces to the real sector are also relatively high. A large amount of financial assets indicates this in the form of non-financial corporate equity in some provinces, which reach more than $50 \%$, such as East Kalimantan, South Sumatra, West Java, DKI Jakarta, and East Java.

Table 5.

Share of Household Financial Assets by Instruments in the Q4 of 2015

\begin{tabular}{|c|c|c|c|c|c|c|c|c|c|}
\hline \multirow[b]{2}{*}{ Components of Financial Assets } & \multirow[b]{2}{*}{ National } & \multicolumn{8}{|c|}{ Province* } \\
\hline & & DKI Jkt & West Java & East Java & $\begin{array}{c}\text { East } \\
\text { Kalimant } \\
\text { an }\end{array}$ & $\begin{array}{l}\text { North } \\
\text { Sulawesi }\end{array}$ & $\begin{array}{c}\text { North } \\
\text { Sumatera }\end{array}$ & $\begin{array}{c}\text { West } \\
\text { Sumatera }\end{array}$ & $\begin{array}{c}\text { South } \\
\text { Sumatera }\end{array}$ \\
\hline Monetary gold and SDRs & - & - & - & - & - & - & - & - & - \\
\hline Currency and Deposits & $42.15 \%$ & $36.66 \%$ & $44.55 \%$ & $49.17 \%$ & $41.33 \%$ & $65.27 \%$ & $87.16 \%$ & $58.68 \%$ & $39.43 \%$ \\
\hline Debt Securities & $0.96 \%$ & $0.04 \%$ & $0.01 \%$ & $0.002 \%$ & - & $0.004 \%$ & $0.004 \%$ & $0.23 \%$ & \\
\hline Loans & $0.02 \%$ & $11.81 \%$ & $0.0001 \%$ & $0.0003 \%$ & - & $0.01 \%$ & $0.01 \%$ & - & $0.00 \%$ \\
\hline Equity & $46.41 \%$ & $50.92 \%$ & $54.89 \%$ & $50.36 \%$ & $58.10 \%$ & $32.59 \%$ & $12.14 \%$ & $41.09 \%$ & $56.37 \%$ \\
\hline Insurance and Pension & $0.07 \%$ & - & - & - & - & - & - & - & - \\
\hline Financial Derivatives & $0.002 \%$ & $0.01 \%$ & - & - & - & - & - & - & - \\
\hline Other Accounts Receivable & $3.10 \%$ & $0.56 \%$ & $0.55 \%$ & $0.47 \%$ & $0.57 \%$ & $2.13 \%$ & $0.69 \%$ & - & $4.20 \%$ \\
\hline Total & $100 \%$ & $100 \%$ & $100 \%$ & $100 \%$ & $100 \%$ & $100 \%$ & $100 \%$ & $100 \%$ & $100 \%$ \\
\hline
\end{tabular}

Source: NBS \& RBS (2015)

* Some provinces can not be shown because the data are not complete

6 The size of each sector's nodes, is based on the Gross Exposure value of total financial assets plus total liabilities; Edges or lines are vague/invisible does not mean there is no connection between sectors, but there is a connection with a relatively small nominal. 
Based on the financing aspect, both national and regional, the source of household financing outside the income is still dominated by debt in the form of loans, primarily from banking. Nationally, household debt in the form of loans reached $96.86 \%$, of which $86 \%$ came from banks.

Table 6.

Share of Household Liability by Instruments in the Q4 of 2015

\begin{tabular}{|c|c|c|c|c|c|c|c|c|c|}
\hline \multirow[b]{2}{*}{ Components of Financial Assets } & \multirow[b]{2}{*}{ National } & \multicolumn{8}{|c|}{ Province } \\
\hline & & DKI Jkt & West Java & East Java & $\begin{array}{c}\text { East } \\
\text { Kalimant } \\
\text { an }\end{array}$ & $\begin{array}{l}\text { North } \\
\text { Sulawesi }\end{array}$ & $\begin{array}{c}\text { North } \\
\text { Sumatera }\end{array}$ & $\begin{array}{c}\text { West } \\
\text { Sumatera }\end{array}$ & $\begin{array}{c}\text { South } \\
\text { Sumatera }\end{array}$ \\
\hline Monetary gold and SDRs & - & - & - & - & - & - & - & - & - \\
\hline Currency and Deposits & - & - & - & - & - & - & - & - & - \\
\hline Debt Securities & - & - & - & - & - & - & - & - & - \\
\hline Loans & $96.85 \%$ & $94.53 \%$ & $98.42 \%$ & $98.3600 \%$ & $97.27 \%$ & $99.65 \%$ & $98.53 \%$ & $99.29 \%$ & $89.73 \%$ \\
\hline Equity & - & - & - & - & - & - & - & - & - \\
\hline Insurance and Pension & - & - & - & - & - & - & - & - & - \\
\hline Financial Derivatives & $0.01 \%$ & $0.06 \%$ & - & - & - & - & - & - & - \\
\hline Other Accounts Receivable & $3.14 \%$ & $5.41 \%$ & $1.58 \%$ & $1.64 \%$ & $2.73 \%$ & $0.35 \%$ & $1.47 \%$ & $0.71 \%$ & $10.27 \%$ \\
\hline Total & $100 \%$ & $100 \%$ & $100 \%$ & $100 \%$ & $100 \%$ & $100 \%$ & $100 \%$ & $100 \%$ & $100 \%$ \\
\hline
\end{tabular}

Source: NBS \& RBS (2015)

* Some provinces can not be shown because the data are not complete

Although most of the region is exposed to banking through loans with a share of above $90 \%$, household credit risk remains relatively well maintained which is reflected in the average Non-Performing Loan (NPL) of local households that is still below the minimum of $5 \%$. However, there are several provinces with household NPL values above national NPLs that need to be of concern to policymakers.

Table 7.

Share of Household Lending by Source

\begin{tabular}{lrrrrrrrrr}
\hline & & \multicolumn{10}{c}{ Province $^{*}$} \\
\cline { 3 - 10 } Components of Financial Assets & National & DKI Jkt & West Java & East Java & $\begin{array}{c}\text { East } \\
\text { Kalimantan }\end{array}$ & $\begin{array}{c}\text { North } \\
\text { Sulawesi }\end{array}$ & $\begin{array}{c}\text { North } \\
\text { Sumatera }\end{array}$ & $\begin{array}{c}\text { West } \\
\text { Sumatera }\end{array}$ & $\begin{array}{c}\text { South } \\
\text { Sumatera }\end{array}$ \\
\hline Banking & $83 \%$ & $97 \%$ & $99 \%$ & $98 \%$ & $100 \%$ & $100 \%$ & $97 \%$ & $100 \%$ & $97 \%$ \\
IKNB & $12 \%$ & $2 \%$ & $1 \%$ & $2 \%$ & - & - & $3 \%$ & - & $3 \%$ \\
Non-Financial Institution & $5 \%$ & $1 \%$ & - & - & - & - & - & - & - \\
Total & $100 \%$ & $100 \%$ & $100 \%$ & $100 \%$ & $100 \%$ & $100 \%$ & $100 \%$ & $100 \%$ & $100 \%$ \\
\hline
\end{tabular}

Source : NBS \& RBS (2015)

* Temporary data (some provinces can not be shown because the data are not complete)

\subsection{Vulnerability Analysis Using a Financial Margin Approach (FMA)}

The analysis of household vulnerability using financial margin indicator showed that the overall result from the income approach tends to be overestimated compared to the expenditure approach. This is caused by the use of household income value in an income approach which tends to bias downward. Based on the expenditure approach, the share of vulnerable households from the total households owed to banks is $14 \%$ with debt holdings of $45 \%$. While in the income approach, the share of vulnerable households that is borrowed to banks reached $43 \%$ with debt ownership of $63 \%$. 


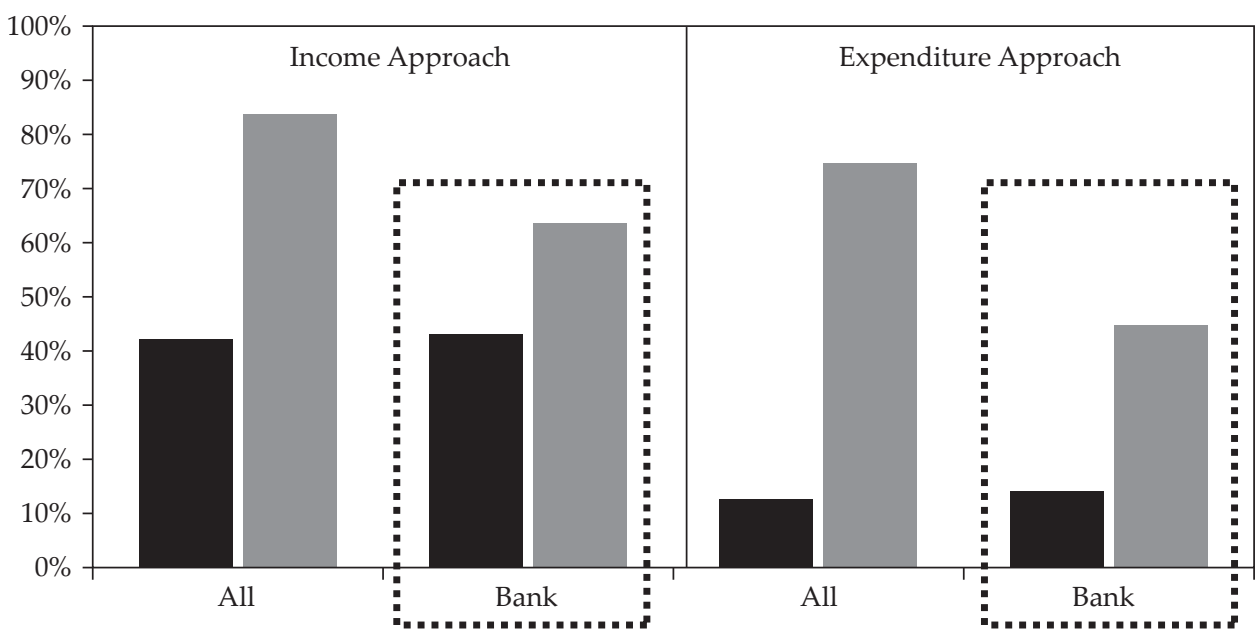

$\%$ Vulnerable Household

Debt Ownership by Vulnerable Household

Graph 6. Share of household Vulnerability and Share of Debt Ownership by Vulnerable Household

The relatively high share of vulnerable households that have the debt to banks in 2015, especially in the income approach implies that banks face high credit risk, especially if the household is experiencing difficulties in fulfilling its obligations. This is in line with the relatively high Non-Performing Loans (NPL) of individual banking loans in 2015 which was $2.40 \%$. The increased NPLs for individual loans are suspected to be a result of the ongoing phase of the economic slowdown in 2015, where the slowdown has put pressure on both consumption and the ability to repay household debt (KSK, 2016).

By income group, both the income approach and the expenditure approach tend to show the same return pattern in which high-income households have the relatively large share of vulnerable and high debt holdings. Top debt holdings are triggered by the ease of access of high-income households to the financial system, the presence of large asset holdings as debt guarantees, predictable financial returns, and long-term revenue holdings. 


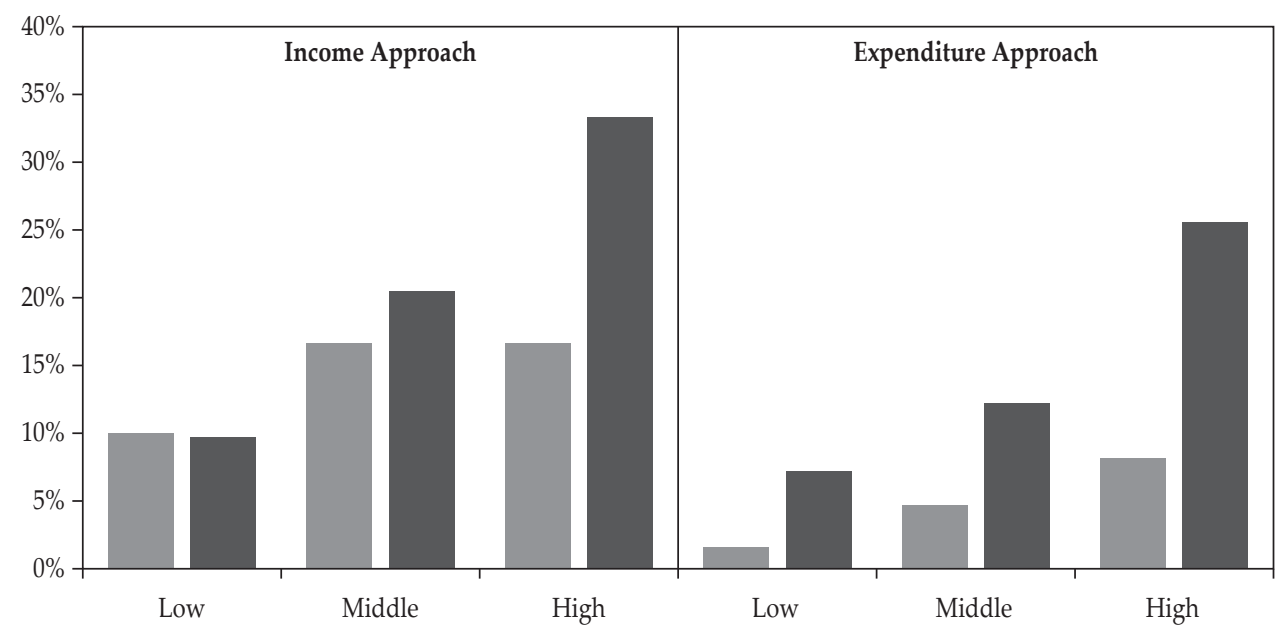

\% Vulnerable Household — \% Debt Ownership by Vulnerable Household

Graph 7. Share of Household Vulnerability and Share of Debt Ownership based on Revenue ${ }^{7}$

The large share of vulnerable households and high bank debt holdings by high-income households implied that these households tend to have a greater likelihood of default when experiencing financial deficits and insufficient liquid assets to cover the entire short-term debt. Nevertheless, the potential risk of these households in experiencing financial pressures is relatively small considering the ownership of assets that tend to be large as it can be used as a defensive strategy in closing the deficit. The survival strategy that can be done by the household is selling the productive asset and withdrawing the savings.

Another thing that needs attention is the relatively large share of vulnerable households coming from low-income groups. The result of the analysis, using the income approach, showed that the share of vulnerable households reaches $10 \%$ with a bank debt ownership of $10 \%$. Low-income groups have a higher risk of experiencing distress which may impact on difficulties in meeting basic needs and paying the debt to banks. The difficulty of fulfilling low-income household obligations to banks in 2015 is also indicated by the high debt service ratio of lowincome households in the second semester of 2015 which reached $2.34 \%$ (KSK, 2016).

The result of the spatial analysis of household vulnerability showed that East Kalimantan is the province with the highest share of vulnerable households and the highest share of debt ownership compared to other provinces. The high share of bank debt ownership by households in East Kalimantan is caused by the ease of access to banking services. In SNRT 2015, 30\% of households in East Kalimantan

7 High income $>\operatorname{Rp} 6,876,000$, Medium income $=\operatorname{Rp} 2,631,000-\operatorname{Rp} 6.875 .000$, and Low income $<\operatorname{Rp} 2,630,000$ 
province can access banking services with an average distance of less than $1 \mathrm{~km}$. In addition to East Kalimantan, there are two other provinces with a share of bank debt owned by vulnerable households above 5\%, i.e., South Sumatra and West Java.

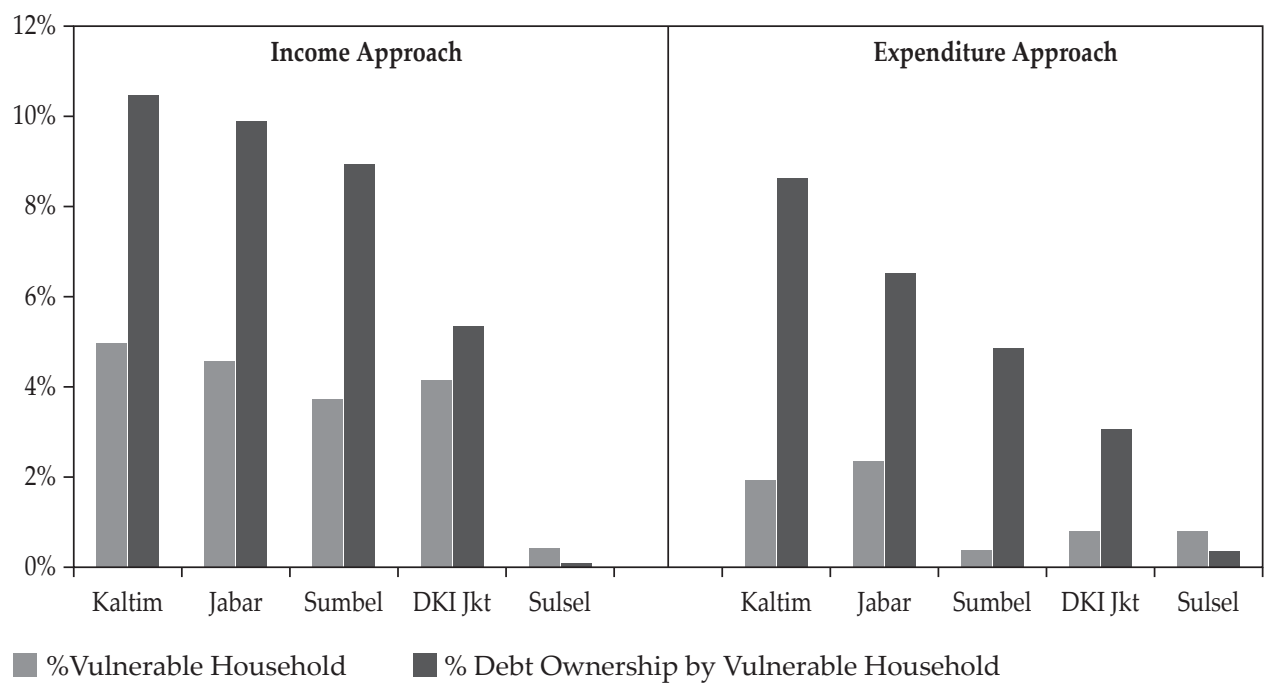

Graph 8. Share of Household Vulnerability and Share of Debt Ownership based on Provinces

Based on household demographic characteristics, the results of the analysis with both approaches showed that vulnerable households exposed to the risk of default are male-headed households who are productive, married with high school degree, and jobs. Also, sensitive households also have exposure to banks through debt instruments with relatively high share. The results are similar to those of Pratama \& Hidayat (2015) study in analyzing the vulnerability of households using financial margin through the Indonesia Family Life Survey (IFLS) data in 2007. From the results of this study, male-headed households and productive age tend to have a high vulnerability with the share of banking debt ownership which is also relatively large. 



Graph 9. Share of Household Vulnerability and Share of Debt Ownership based on Demography 


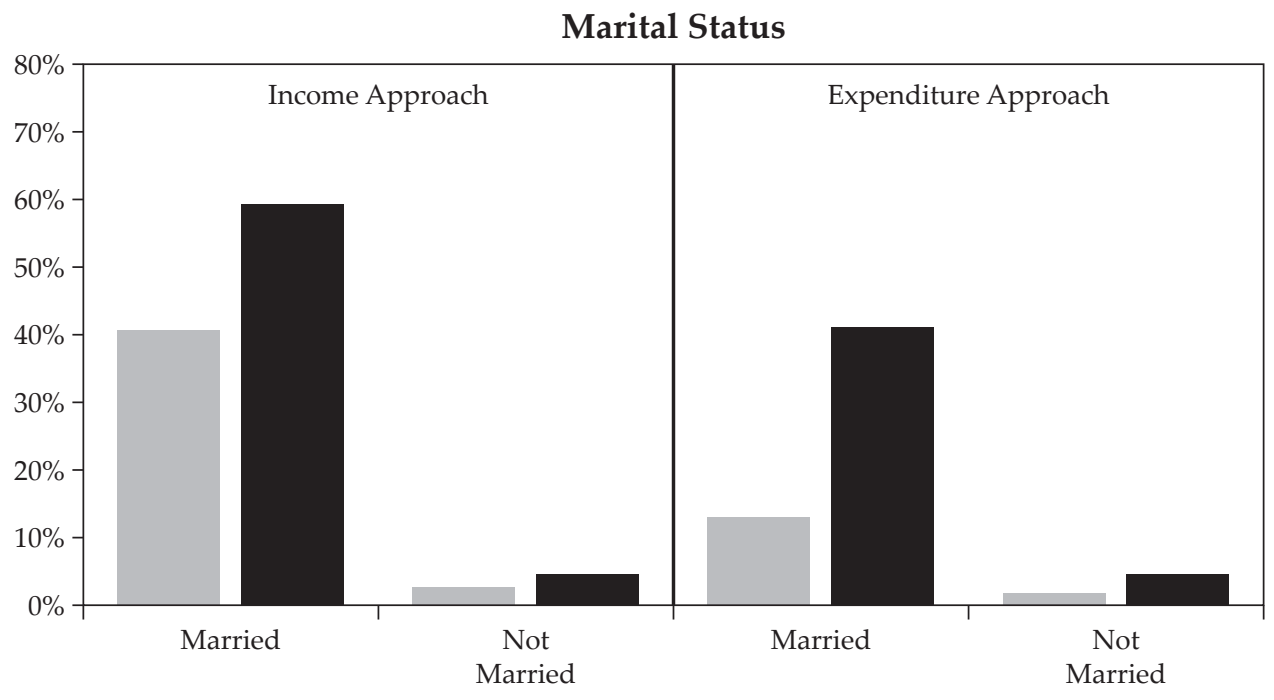

\%Vulnerable Household — @ Debt Ownership by Vulnerable Household

\section{Education}

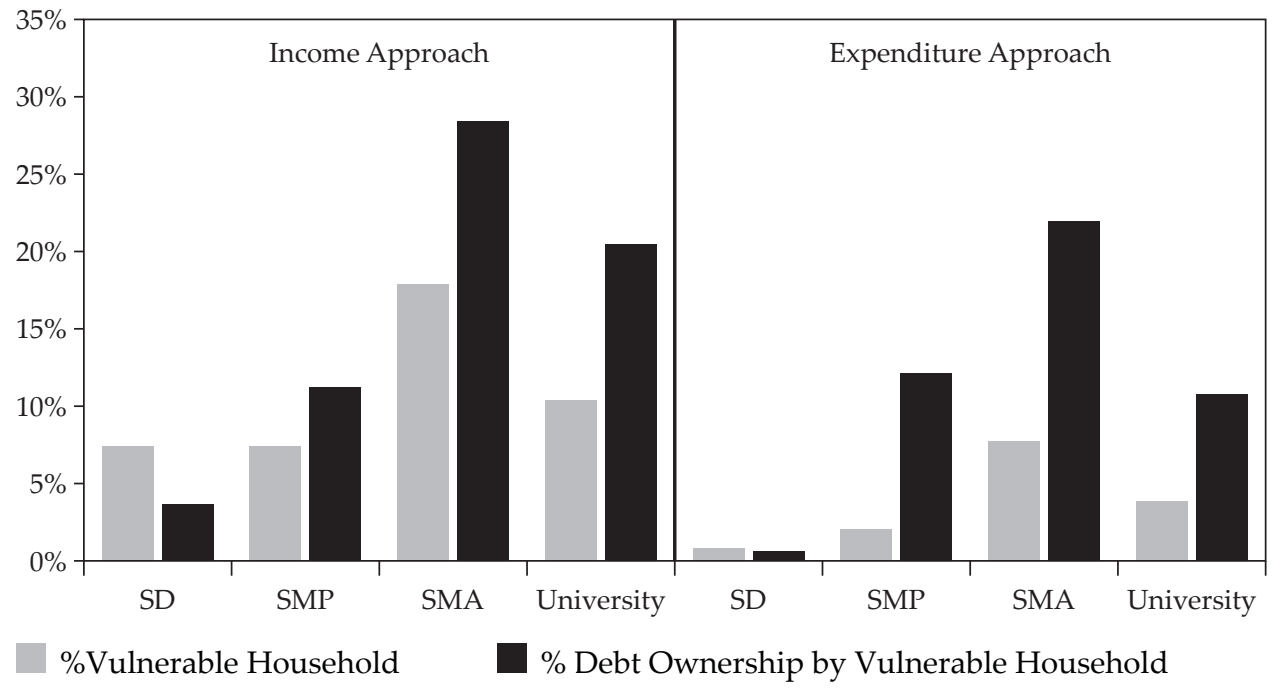

Graph 9. Share of Household Vulnerability and Share of Debt Ownership based on Demography (Continued) 


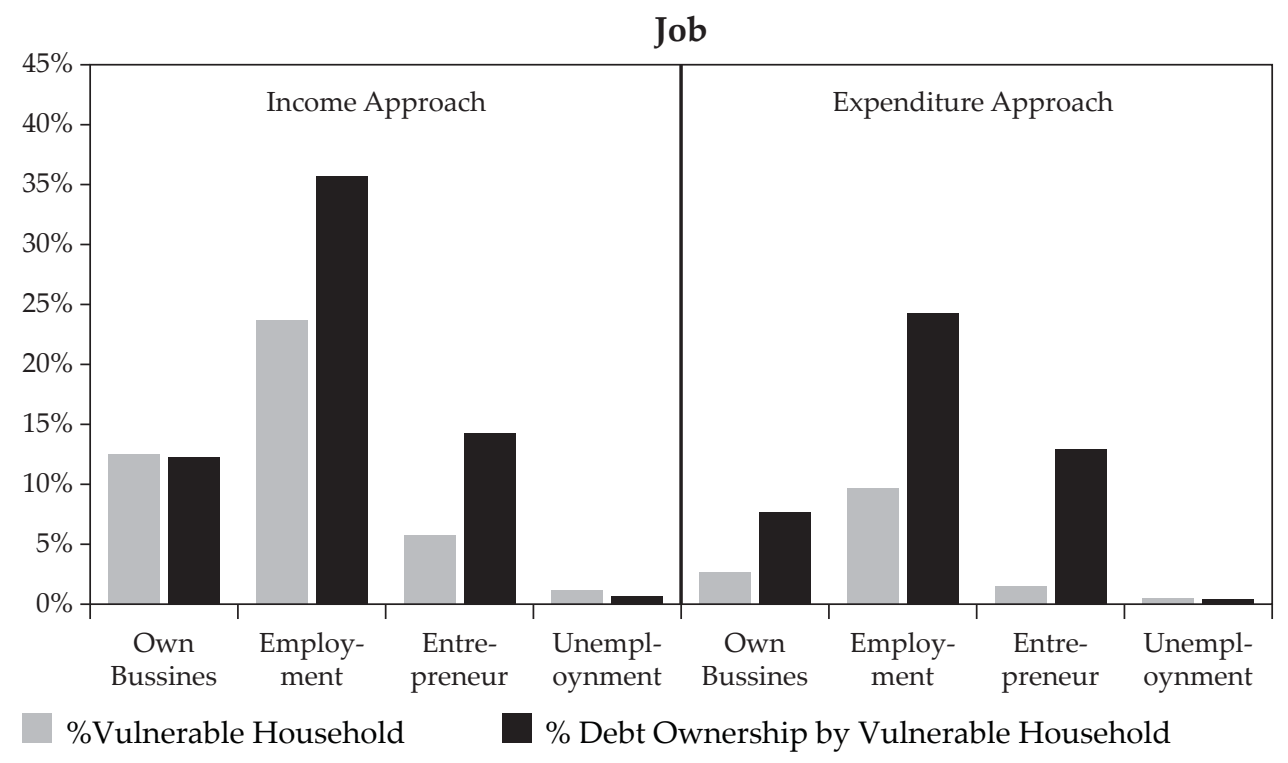

Graph 9. Share of Household Vulnerability and Share of Debt Ownership based on Demography (Continued)

Overall, the household vulnerability analysis conducted by utilizing the 2015 SNRT data indicated that there is a positive correlation between the number of vulnerable households with bank debt ownership by the household. This is also in line with Vatne's (2007) study which found that there is a positive correlation between the default rate and the debt held by vulnerable households.

The vulnerability analysis of households based on the above characteristics can be summarized in an analytical matrix that provides a general correlation between the number of vulnerable households with the bank debt they have. Chart 4 shows that households with elderly, low-educated (primary and junior secondary) heads with no permanent employment, no marital status (or headed by a woman) tend to have relatively small banking debt with a relatively small number of vulnerable households.

While households with the university as the last education of the head have jobs as entrepreneurs and tend to have large bank debt, but with a relatively small number of vulnerable households, indicating that the risks in this household group are relatively well maintained, given that the head of households works as entrepreneurs and can use bank debt for the capital venture. The return from the use of debt to investment and other financing makes this household have a relatively small potential to default.

The relatively high potential of default risk tends to come from household groups with household heads at productive age (25-59 years old), high school education, permanent employment, married, and men (head). This household group has considerable debt exposure to banks, and the number of vulnerable households from this group is also relatively high. 


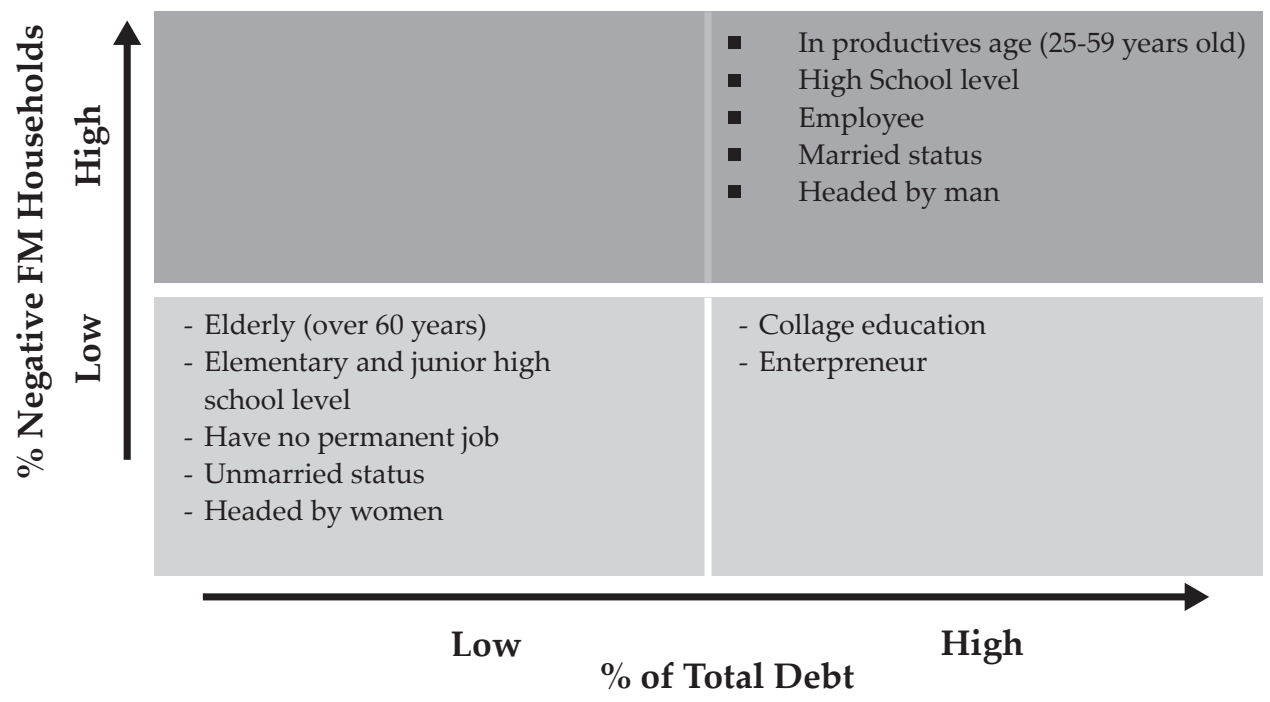

Chart 4. Vulnerability Analysis Matrix

Based on Household Characteristics

\subsection{Coping Strategies Analysis of Household in Indonesia}

Coping strategies are analyzed to identify household vulnerability based on survival strategies adopted by households in facing financial pressures. Based on data from the 2015 SNRT, $29 \%$ of households with debt face financial difficulties in the form of difficulties in meeting the needs of life, while $23 \%$ of households have difficulties in paying the debt over the past year.

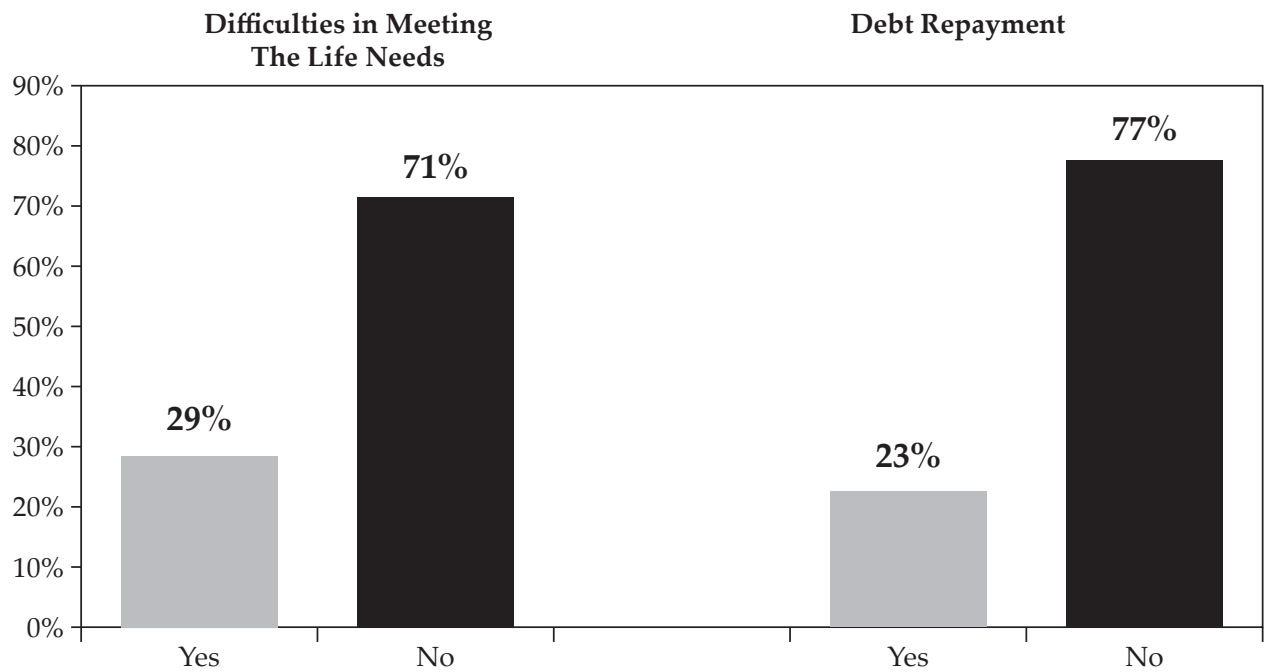

Graph 10. Share of Household Difficulties in Meeting The Life Needs and Debt Repayment 
In anticipating the risk of more profound financial pressures, $61 \%$ of households choose adaptive strategies by reducing expenditure. Other preferred strategies including selling valuables $(40 \%)$, borrowing food or money from relatives and family $(39 \%)$, withdrawing money from savings (37\%), and finding additional employment (27\%).

Referring to the heatmap coping strategies contained in the Food Security \& Early Warning Vulnerability USAID (1999) assessment manual, the level of vulnerability of households with debt is still within the moderate zone because the majority of households still rely on adaptation strategies by reducing expenditure in response to financial pressure. However, it is important to be aware that in addition to adaptation strategy, cumulatively, household also chooses several divestment strategies in liquid assets, causing higher levels of vulnerability to be faced. Several divestiture strategies in the liquid assets carried out by these households include selling valuables owned, borrowing money from relatives, and withdrawing savings.



Chart 5. Heatmap Coping Strategies of Households in Indonesia

Also, Indonesian households also tend to divest their earning assets if the liquidity strategy of adaptation and divestment took cannot cover the financial deficit. Failure to divest productive asset strategy will lead to the loss of household ability to repay short-term debt as well as long-term debt so that the vulnerability of the household is in extreme conditions and can affect the financial sector as well as the imbalance of the financial system as a whole.

Based on income groups, households that have debts and difficulties meeting the living needs in the past year are dominated by high-income households. Meanwhile, households that have difficulties to pay the debt (majority) come from the middle-income household group. 
Difficultiesin Fulfilling Life Needs

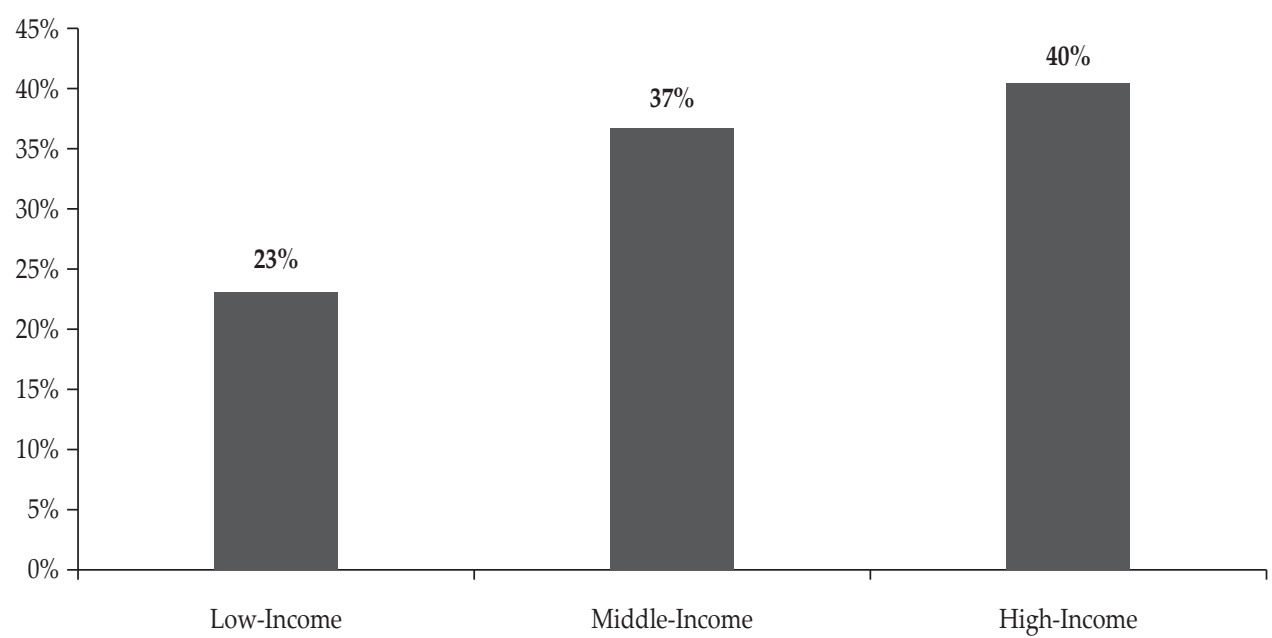

Difficulties in Repaying Loans

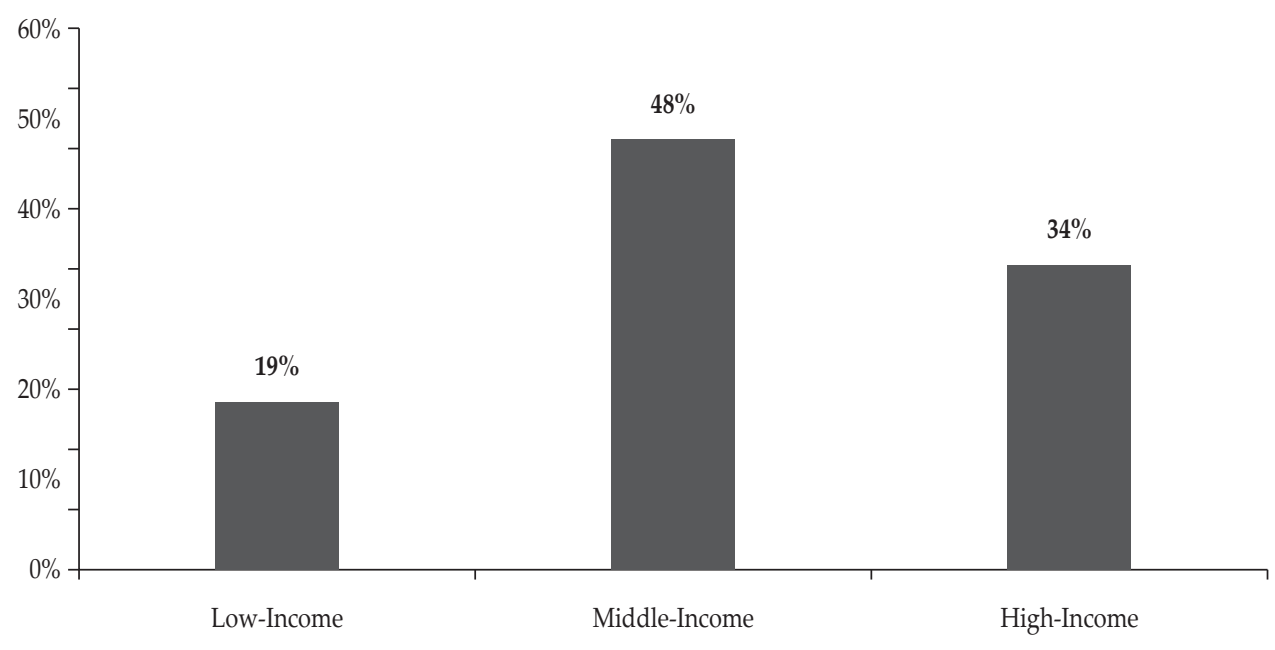

Graph 11. Share of Households having Difficulties in Fulfilling the Living Needs and Paying the Debt

The most survival strategy chosen by Indonesian households from high, middle and low-income groups is an adaptation strategy through the reduction of expenditure. Alternatively, high-income household groups also tend to withdraw savings, so there needs to be vigilance from banks to anticipate liquidity risks triggered by massive withdrawals from households. Furthermore, based on the 2015 SNRT, survival strategies chosen by households by income group are as follows. 


\begin{tabular}{|c|c|c|}
\hline High Income & Middle Income & Low Income \\
\hline $\begin{array}{l}\text { 1. Reduce expenses } \\
\text { 2. Withdraw money from } \\
\text { savings } \\
\text { 3. Selling valuables goods } \\
\text { 4. Borrow food or money from } \\
\text { family and friends } \\
\text { 5. Doing additional work }\end{array}$ & $\begin{array}{l}\text { 1. Reduce expenses } \\
\text { 2. Selling valuables goods } \\
\text { 3. Borrow food or money from } \\
\text { family and friends } \\
\text { 4. Doing additional work } \\
\text { 5. Withdraw money from } \\
\text { savings }\end{array}$ & $\begin{array}{l}\text { 1. Reduce expenses } \\
\text { 2. Selling valuables goods } \\
\text { 3. Borrow food or money from } \\
\text { family and friends } \\
\text { 4. Withdraw money from } \\
\text { savings } \\
\text { 5. Work longer to earn extra } \\
\text { money }\end{array}$ \\
\hline
\end{tabular}

Chart 5. Household Coping Strategy by Revenue Group

\section{CONCLUSION}

This paper analyzes the vulnerability of households in Indonesia at the micro level by reviewing the financial margin, and in aggregate using the Balance Sheet Approach. To identify the characteristics and risk profile of the household sector, this paper concluded that the household sector in Indonesia is quite solvent and sound, both regarding solvency and the adequacy of liquidity. Besides, the household sector is the sector with the largest financial surplus that plays an essential role as it is the largest source of domestic financing in Indonesia.

Related to risk profile, this paper concludes that there is a great risk potential considering the financial interconnection between household sector and a nonfinancial corporation which is high, as well as the interconnection between household sector and banking.

Through the financial margin approach, the household risk profile analysis in this paper provides a third conclusion that the potential for relatively high default risk comes from household groups with heads of households at productive age (25-59 years old), high school education level, employee, married, and men leader.

Finally, from the analysis of heatmap coping strategies, the fourth conclusion of this paper is that household vulnerability is still in a moderate zone with coping strategies in the form of reduced spending when there is financial pressure. However, this paper emphasizes the need for caution because cumulatively, the household vulnerability has the potential to rise to higher levels (high and extreme), and this can have an impact on the imbalances of the financial system.

As a further development effort, this paper suggests (i) using sensitivity analysis, through household resilience testing of a number of shock scenarios, among others from interest rate increases, unemployment rate and asset price reductions, and impacts; (ii) the need for refinement of SNRT 2015 data, particularly regarding the scope of respondents, question instruments regarding data income, and questions related to coping strategies with reference to the internationally used heatmap coping strategies; (iii) use the results and conclusions in this paper as initial information on developing debt to income ratio instruments within the macroprudential policy framework. 


\section{REFERENCE}

Abubakar, Arlyana., et al. (2015). Kerangka dan Analisis Indikator Ketidakseimbangan Keuangan dalam National dan Regional Balance Sheet (Versi I). Bank Indonesia.

Armas, JCA. (2016). Balance Sheet Analysis: A New Approach to Financial Stability Surveillance. Bangko Sentral ng Pilipinas.

Bank Indonesia. (2016). Kajian Stabilitas Keuangan - Mitigasi Risiko Sistemik untuk Menjaga Stabilitas Sistem Keuangan dan Mendorong Intermediasi di Tengah Tantangan Global dan Domestik. KSK Maret 2016.

Bilston, Tom., Johnson, Robert \& Read, Matthew. (2015). Stress Testing the Australian Household Using the HILDA Survey. Research Discussion Paper. Reserve Bank of Australia.

Craig, Sean. (2015). Risk and Spillovers: Use of National Balance Sheet Data. Material for Meeting of the IMF Government Finance Statistics Advisory Committee. Washington DC.

Haim, Yair., Levy, Roee. (2007). Using the Balance Sheet Approach in Financial Stability Surveillance: Analyzing the Israeli Economy's Resilience to Exchange Rate Risk. Financial Stability Area. Bank of Israel.

Hoogeveen, Johannes., Tesliuc, Emil., \& Vakis, Renos. (2004). A Guide to the Analysis of Risk, Vulnerability and Vulnerable Groups. Worldbank \& University of Stanford.

IMF. (2015). Balance Sheet Analysis in Fund Surveillance. Policy Paper International Monetary Fund (IMF). Juni 2015.

IMF. (2015). Balance Sheet Analysis in Fund Surveillance - Reference Note. Policy Paper International Monetary Fund (IMF). Juli 2015.

Johanson, Martin W., and Persson, Mattias. (2006). Swedish Households' Indebtedness And Ability To Pay - A Household Level Study. Penning - OCH valutapolitik 3/2006. Sveriges Riks bank.

Nicolas, Albacete., and Fessler, Pirmin. (2009). Stress Testing Austrian Households. Oesterreichische National Bank.

Pratama, Alvin., and Hidayat, Taufik. (2015). Indonesia Households' Financial Vulnerability. Paper submitted to Bank Indonesia.

PEP-CBMS Network Coordinating Team. (2011). Definition and Types of Shocks and Coping Strategies to be Monitored. Material for Technical Workshop on Monitoring Household Coping Strategies During Complex Crises March 2011. Poverty Environment Partnership (PEP) - United Nations Development Program (UNDP) \& Community Based Monitoring System International Network (CBMS).

Ryan, Paul., and Stone, Tahlee. (2009). Household Wealth in Australia: Evidence from the 2014 HILDA Survey. Reserve Bank of Australia.

Santoso, Wimboh., and Sukada, Made. (2009). Risk Profile of Households and The Impact on Financial Stability. BIS Papers No 46.

WHO/EHA. (1999). Emergency Health Training Programme for Africa - Coping Mechanism. Draft 1-1999.

Yuventus, Effendi. (2015). The Indonesia Households' Stress Testing: A Micro Simulation Approach. Fiscal Policy Agency. Ministry of Finance Indonesia. 
Vatne, BH. (2006). How Large Are The Financial Margin Of Norwegian Households? An Analysis Of Micro Data For The Period 1987 - 2004. Economic Bulletin 4/06 (Vol.77) 173-180. Central Bank of Norway.

Vatne, BH.(2007). Financial Margin in Norwegian Household - An Analysis of Micro Data for the Period 1987 - 2003. EIFC Bulletin No 25. Central Bank of Norway. 
This page is intentionally left blank 